\section{Club Notes}

\section{ENTOMOLOGICAL MEETING}

The twelfth annual meeting of the Entomological Society of Saskatchewan was held December 11, 1964, at Jay Dees Restaurant, Saskatoon.

Guest speakers were, Dr. J. Maybank, Saskatchewan Research Council and Dr. H. E. Robertson, Director, Provincial Laboratories, Regina. Papers presented by members of the Society covered topics ranging from an embryological study of the blister beetles to tips on outdoor photography of insects in general.

The meeting was followed in the evening by a banquet on the premises at which Mr. Bob Adams, Canadian Olympic coach, gave an interesting talk on his impressions of the 1964 Olympics in Japan.

Officers Elect for 1965: Past President, M. Taylor (Saskatoon); President, M. N. MacLeod (Saskatoon); Vice-President, L. O. T. Peterson (Indian Head); Secretary-Treasurer, W. W: A. Stewart (Saskatoon).

The Society membership is open to anyone interested in entomology. Amateur entomologists interested in becoming members are invited to contact the Secretary-Treasurer, Mr. W. W. A. Stewart, Canada. Agricultural Research Station, University Sub Post Office, University of Saskatchewan, Saskatoon.

\section{BLUE JAY BACK COPIES WANTED}

The College of Education Library wishes to enlist the assistance of Blue Jay readers in completing its collection of the Blue Jay. In order to make past issues more readily available to the students of the College of Education, we propose to have them bound and placed on the open shelf. Unfortunately, our collection is incomplete. We would very much appreciate information regarding the following: Volumes 1, 2, 3, 5, 6, 7; Volume 4, No. land 2; Volume 12, No. 3; and Volume 14, No. 2. We have a few duplicate copies and may be able to help you complete your collection.-Murray $C$. Shepherd, College of Education, University of Saskatchewan, Regina Campus, Regina.

\section{SOCIETY HONOURED BY BEQUEST}

On November 24, 1964, the executive of the Saskatchewan Natural History Society was notified that the late Constance Mary Wait of Saskatoon had bequeathed the sum of $\$ 500.00$ to the Society. This stirring gesture indicates Mrs. Wait's devotion to natural history and conservation, and her faith in our Society. This is an honour which should move us all to make a greater effort toward meeting our objectives.

\section{FREEMAN F. KING SCHOLARSHIP}

The Victoria Natural History Society is setting up a scholarship at the University of Victoria in the name of Freeman F. King, to recognize his untiring efforts on behalf of young people. Mr. Freeman King, naturalist, writer, and outdoors-man, has spent the greater part of his life working with young people, first with the Boy Scouts and later through the Victoria Natural History Society. During his leadership of the Junior Branch of the Victoria Natural History Society he has conducted five annual summer camps for young naturalists and has inspired a number of young people to continue studies at the university. In 1964 he conducted the first Audubon Young Naturalists Camp in B.C.

The income from the trust fund being established will be used to award a scholarship in the Natural Sciences to a student selected by the University Scholarship Committee. Your assistance would be greatly apreciated. Cheques sent should be made payable to "The Freeman F. King Scholarship Fund, in trust" and mailed to Dr. John A. Chapman, Victoria Natural History Society, c/o Provincial Museum, Victoria, B.C.-John A. Chapman, Victoria. 